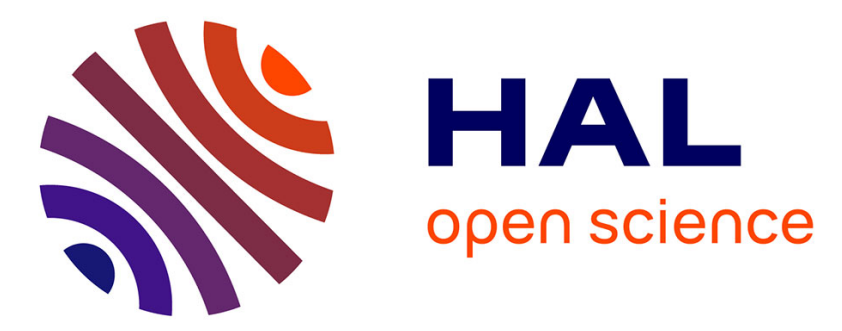

\title{
Past productivity variations and organic carbon burial in the Gulf of Aden since the Last Glacial Maximum
}

\author{
Wiem Fersi, Franck Bassinot, Anne-Marie Lézine
}

\section{To cite this version:}

Wiem Fersi, Franck Bassinot, Anne-Marie Lézine. Past productivity variations and organic carbon burial in the Gulf of Aden since the Last Glacial Maximum. Quaternaire, 2016, 27 (3), pp.213-226. 10.4000/quaternaire.7655 . hal-01414689

\author{
HAL Id: hal-01414689 \\ https://hal.science/hal-01414689
}

Submitted on 19 Oct 2020

HAL is a multi-disciplinary open access archive for the deposit and dissemination of scientific research documents, whether they are published or not. The documents may come from teaching and research institutions in France or abroad, or from public or private research centers.
L'archive ouverte pluridisciplinaire HAL, est destinée au dépôt et à la diffusion de documents scientifiques de niveau recherche, publiés ou non, émanant des établissements d'enseignement et de recherche français ou étrangers, des laboratoires publics ou privés. 


\title{
PAST PRODUCTIVITY VARIATIONS AND ORGANIC CARBON BURIAL IN THE GULF OF ADEN SINCE THE LAST GLACIAL MAXIMUM
}

\author{
Wiem FERSI ${ }^{1,2}$, Franck BASSINOT ${ }^{1} \&$ Anne-Marie LÉZINE ${ }^{2}$
}

\begin{abstract}
We reconstructed the evolution of marine primary productivity across the last deglaciation in the Gulf of Aden based on micropaleontological and sedimentological data from marine core MD92-1002. Dinoflagellate cysts analysis suggests that the glacial period was characterized by weakened upwellings and well ventilated bottom water. Primary productivity increased from $14.5 \mathrm{ka}$ with a maximum between 12.6 and $10.8 \mathrm{ka}$, then declined during the Holocene. Maximum of primary productivity in the Gulf of Aden took place about $3 \mathrm{ka}$ earlier than the maximum of upwelling intensity off the Oman margin, and was not phase-locked with the maximum of boreal summer insolation. XRF-derived bromine contents mimic the variations of Total Organic Carbon (TOC) in core MD92-1002. Both records show a strong glacial/interglacial signal that is largely decoupled from our reconstruction of surface productivity, suggesting that total organic content in core MD92-1002 is mainly controlled by preservation at the sea floor.
\end{abstract}

Keywords: Gulf of Aden, dinoflagellate cysts, productivity, organic carbon, monsoon

\section{RÉSUMÉ}

\begin{abstract}
FLUCTUATIONS DE LA PRODUCTIVITÉ MARINE DANS LE GOLFE D’ADEN DEPUIS LE DERNIER MAXIMUM GLACIAIRE

Nous avons reconstruit l'évolution de la productivité marine primaire dans le Golfe d'Aden depuis le dernier maximum glaciaire à partir de données micro-paléontologiques et sédimentaires de la carotte MD92-1002. L'analyse des kystes de dinoflagellés suggère que la période glaciaire est caractérisée par une activité réduite des upwellings et par des eaux profondes bien oxygénées. La productivité primaire augmente (et l'oxygénation des eaux profondes se réduit) à partir de 14,5 ka et atteint son maximum entre 12,6 et 10,8 ka, pour diminuer ensuite pendant l'Holocène. Dans le Golfe d'Aden, la productivité primaire aurait ainsi atteint son maximum vers $3 \mathrm{ka}$ avant le pic d'intensité de l'upwelling le long de la marge d'Oman correspondant au maximum d'insolation de l'été boréal. Les variations du Brome (Br), du Carbone Organique Total (COT) et de la concentration en micro-organismes planctoniques sont fortement corrélées entre elles dans la carotte MD92-1002. Ces paramètres montrent un fort signal Glaciaire/ Interglaciaire qui est donc largement découplé de la productivité de surface. Nos données suggèrent donc que la teneur en matière organique totale dans la carotte MD92-1002 est essentiellement contrôlée par la préservation sur le fond marin.
\end{abstract}

Mots-clés : Golfe d'Aden, kystes de dinoflagellés, productivité, carbone organique, mousson

\section{1 - INTRODUCTION}

The Arabian Sea is characterized by one of the highest primary productivity in the modern world ocean. On the western side, primary productivity shows a strong annual variability that results from the seasonal reversal of monsoon winds, which drive large upwelling systems along the continental margins. In summer (May-September), differential land-ocean heating leads to intense southwest (SW) monsoonal winds (fig. 1, left; Wyrtki, 1973; Pickard \& Emery, 1982). The primary productivity reaches its maximum and high oxygen consumption at depth induces a strong Oxygen Minimum
Zone (OMZ) from about 100 to 1,500 m (Jean-Baptiste et al., 1990; Van Couwelaar, 1997). In contrast, during the northeast (NE) monsoon (December-February), wind monsoonal circulation reverses with winds blowing mainly from the Northeast, resulting in the weakening of Eckman pumping along the western side of the Arabian Sea (fig. 1, right).

Owing to the potential importance of these massive upwelling systems on the carbon cycle and their interest for inferring past changes in monsoon wind intensity, several studies have been devoted to reconstruct and understand past changes of primary productivity in the Arabian Sea using sedimentological, geochemical

\footnotetext{
${ }^{1}$ Laboratoire des Sciences du Climat et de l'Environnement/IPSL, CEA-CNRS-UVSQ - UMR8212, CEA Saclay, l'Orme des Merisiers, FR-91191 GIF-SUR-YVETTE cedex. Emails : wiem.fersi@lsce.ipsl.fr; franck.bassinot@lsce.ipsl.fr

${ }^{2}$ Sorbonne Universités, UPMC-Univ Paris 06, CNRS-IRD-MNHN, LOCEAN/IPSL laboratory, 4 place Jussieu, FR-75005

PARIS. Email : anne-marie.lezine@locean-ipsl.upmc.fr
} 


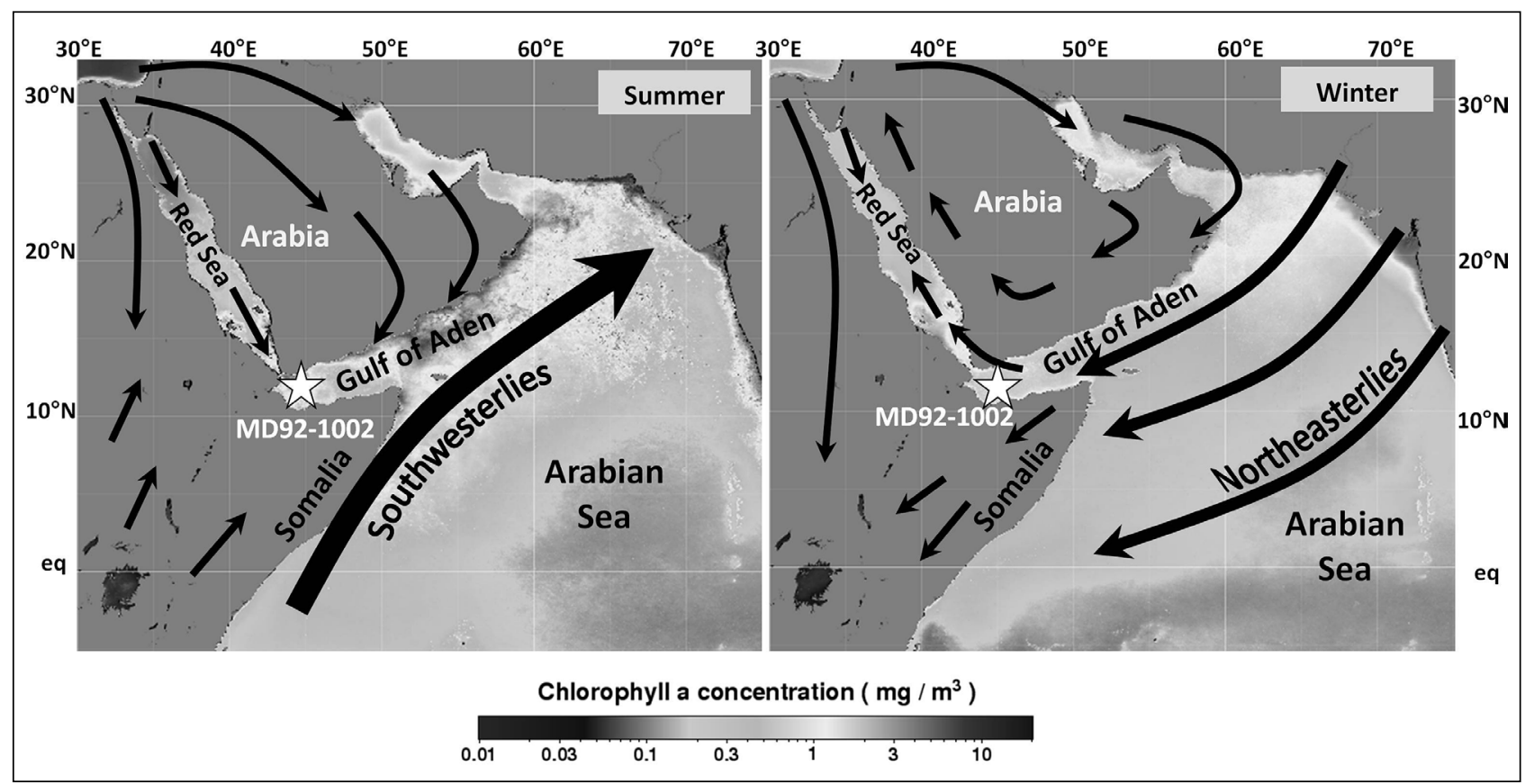

Fig. 1: Seasonal distribution of chlorophyll a concentration $\left(\mathrm{mg} / \mathrm{m}^{3}\right)$ in the Arabian Sea surface water between 1997 and 2010 according to the SeaWiFS project (oceancolor.gsfc.nasa.gov/cgi/l3).

Darj grey areas represent high biological activity, while light grey areas are less rich in nutrient content. General seasonal wind pattern in the Arabian Sea area is shown by black arrows. Location of core MD92-1002 is shown on the map.

Fig. 1 : Distribution saisonnière de la concentration en chlorophylle a $\left(\mathrm{mg} / \mathrm{m}^{3}\right)$ dans les eaux de surface de la mer d'Arabie entre 1997 et 2010 d'après le projet SeaWiFS (oceancolorgsfc.nasa.gov/cgi/l3). Les zones gris foncé représentent une activité biologique élevée alors que les zones gris clair sont moins riches en éléments nutritifs. La circulation saisonnière des vents dans la mer d'Arabie est figurée par des flèches noires. La carte montre la localisation de la carotte MD92-1002.

and micro-paleontological records from marine sediments (Prell \& Curry, 1981; Anderson \& Prell, 1991, 1993; Sirocko et al., 1991; Rostek et al., 1997; Schulz et al., 1998; Almogi-Labin, 2000; Agnihotri et al., 2003; Gupta et al., 2003, 2011; Ivanova et al., 2003; Naidu \& Niitsuma, 2003; Ivanochko et al., 2005; Bassinot et al., 2011; Singh et al., 2011). These studies, confirming early modeling results (Kutzbach \& Street-Perrott, 1985), indicate that monsoonal wind intensity varied on a glacial/ interglacial timescale but was mostly driven by low latitude summer insolation forcing, with a strong precession component (e.g. Prell, 1984; Anderson \& Prell, 1993; Clemens et al., 1991), although the exact timing (phase lag) is still debated (e.g. Caley et al., 2011). During the Last Glacial Maximum (LGM), the productivity along the western Arabian Sea was lower due to the weakening of the SW monsoon (Prell \& Van Campo, 1986; Naidu \& Malmgren, 1996; Gupta et al., 2003, 2011). Summer upwelling intensity increases along the last deglaciation and reached a peak at about $9 \mathrm{ka}$, in phase with the maximum of boreal summer insolation paced by the precession of the Earth's orbit (Gupta et al., 2003).

Evolution of past productivity in the Gulf of Aden is not as clearly understood. A reconstruction of productivity changes over the last $530 \mathrm{ka}$ based on foraminiferal assemblages suggests that, on orbital time scales, past changes in productivity were driven by winter monsoon intensity (Almogi-Labin et al., 2000). These results are puzzling since modern hydrographic data indicate that upwellings develop during the summer season in the west of the Gulf of Aden (Morcos \& AbdAllah, 2013). These upwelling cells are not as active as those in the
Arabian Sea and surface nitrate and chlorophyll contents are lower in the Gulf of Aden than along the coasts of Somalia and Oman (Swallow, 1984; Luther \& O’Brien, 1985; Van Couwelaar, 1997).

The Gulf of Aden is a complex area, landlocked between Arabia and the Horn of Africa and at the junction between two orthogonal wind systems during the summer season: SW monsoon winds prevailing to the east of the gulf, and NW winds blowing along the main axis of the Red Sea to the west of the Gulf. In addition, over orbital timescales, this area would not only be affected by changes in low latitude insolation forcing and monsoon dynamics but also by glacio-eustatic variations through their impact on water exchanges with the Red Sea. The recent work of Bouilloux et al. (2013b) suggested that intensity of upwellings in the Gulf of Aden may have influenced changes in the productivity of the southern Red Sea, owing to the anti-estuarine circulation scheme that results in nutrient-rich upper waters being exported to the nutrient-depleted Red Sea.

Our main goal in this work is to reconstruct the temporal evolution of marine primary productivity in the Gulf of Aden over the last $20 \mathrm{ka}$ with a special focus on the last glacial-interglacial transition. During this period, boreal summer insolation showed both a minimum $(\sim 20 \mathrm{ka})$ and a maximum $(\sim 9 \mathrm{ka})$ value, and sea level raised about $\sim 120 \mathrm{~m}$, changing significantly the connection between the Red Sea and the Gulf of Aden though the shallow $(137 \mathrm{~m})$ Bab-el-Mandab strait. In order to reconstruct the productivity changes, we studied dinoflagellate cyst assemblages and changes in the abundance of copepod eggs from a well-dated piston core (MD92-1002) 
retrieved at $\sim 1,327 \mathrm{~m}$, just below the modern limit of the OMZ. We also looked at the organic matter content in the sediment by combining the percentage of Total Organic Carbon (TOC) and XRF-derived bromine content.

\section{2 - MATERIAL AND METHODS}

Core MD92-1002 was collected at a water depth of $1,327 \mathrm{~m}$ in the Gulf of Aden ( $12^{\circ} 011^{\prime} 32^{\prime \prime} \mathrm{N}$; 44 $\left.4^{\circ} 19^{\prime} 02^{\prime \prime} \mathrm{E}\right)$, near the Bab el Mandeb sill during the MD73 Red Sea cruise of the R/V Marion Dufresne in 1992. The 9.5-m-long sedimentary record is continuous and undisturbed. It consists in greenish clay-dominated sediments with pyrite. The biogenic fraction coarser than $150 \mu \mathrm{m}$ includes planktonic foraminifera with rare benthic forms, many pteropods and radiolarian tests. The detrital fraction is composed of carbonates, quartz, aragonite, clay and some heavy minerals like pyrite (Ouahdi, 1997; Bouilloux et al., 2013a,b).

\section{1 - STABLE ISOTOPIC STRATIGRAPHY AND ${ }^{14} \mathrm{C}$ DATING}

Oxygen isotope measurements were performed on shells from the planktonic foraminifera Globigerinoides ruber picked at a resolution of about $5 \mathrm{~cm}$ (Ouahdi, 1997). Results reveal that core MD92-1002 covers the time period since the LGM with an expanded Holocene and a well-developed deglaciation (Ouahdi, 1997; MathienBlard, 2008; Bouilloux et al., 2013a,b). Because the core had been heavily sampled over the years, we could not control the depth of samples initially taken for isotopic stratigraphy relative to our own sampling. Although there was no indication that the cumulative depth used for the initial isotopic stratigraphy might be erroneous, we considered nonetheless that it was important to insure that there was no mismatch between the isotopic stratigraphy and our new data. For this purpose, we decided to perform new $\delta^{18} \mathrm{O}$ analyses on $G$. ruber shells picked from our own samples. New measurements of the isotopic composition of G. ruber (white, sensus stricto morphotype), picked from the size fraction $250-315 \mu \mathrm{m}$, were performed at the Laboratoire des Sciences du Climat et de l'Environnement (LSCE) using a dual inlet Delta Plus mass spectrometer. $\delta^{18} \mathrm{O}$ results are expressed in \%o versus Vienna Peedee belemnite (V-PDB) with respect to NBS 19 and NBS 18 standards. The mean internal analytical reproducibility determined from replicate measurements of a carbonate standard is $\pm 0.05 \%$. New isotopic values are in good accordance with previously published data (fig. 2). One can notice, however, that the deglaciation is somewhat smoother in the new $\delta^{18} \mathrm{O}$ record, which lacks heavy values that had been observed between $\sim 450-550 \mathrm{~cm}$ in the original stratigraphy and were interpreted as potentially associated to the Younger Dryas.

The age model is based on ten AMS ${ }^{14} \mathrm{C}$ dates obtained on shallow dwelling planktonic foraminifera G. ruber and Globigerinoides sacculifer (table 1) at the Laboratoire de Mesures du Carbone 14 (LMC14, Saclay, France). The ${ }^{14} \mathrm{C}$ ages were calibrated to calendar ages using the OxCal 4.2 software (Oxford Radiocarbon Accelerator Unit; Bronk \& Ramsey, 1995, 2001; Reimer et al., 2004) and assuming a global surface reservoir age of $400 \mathrm{yr}$ and a regional correction $\Delta \mathrm{R}=163 \pm 74 \mathrm{yr}$ (Southon et al., 2002). The OxCal software provides us with an estimation of age model uncertainties between control points. All ages are given as calendar age (cal. BP). Figure 2 shows the resulting age-depth profile for core MD921002 as well as the sedimentation rates. Those sedimen-

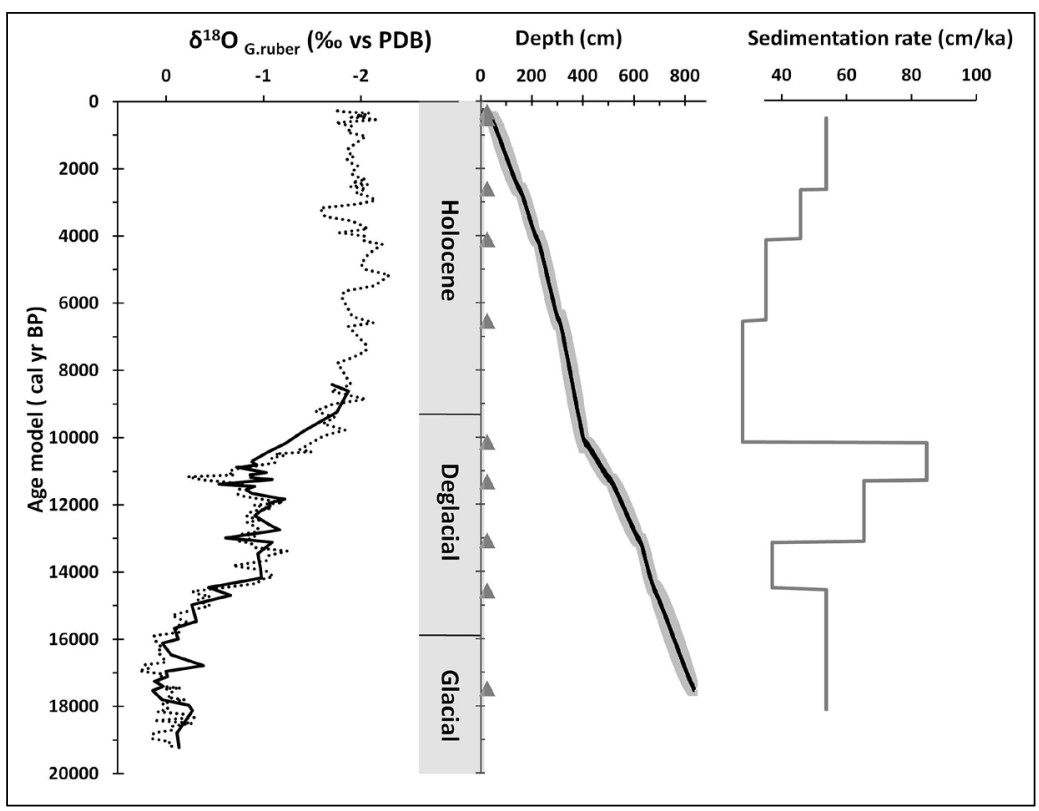

Fig. 2 : Representation of the isotopic stratigraphy of the core MD92-1002, the age model control and the sedimentation rate.

The continuous black curve represents new $\delta^{18} \mathrm{O}_{G}$ ruber data focused on the deglacial period. The age model has been established using Oxcal software (Bronk Ramsey, 1995, 2001; Reimer et al., 2004). Triangles represent ${ }^{14} \mathrm{C}$ dated levels.

Fig. 2 : Représentation de la stratigraphie isotopique de la carotte MD92-1002, du modèle d'âge et de la vitesse de sédimentation. La courbe continue noire représente les nouvelles données de $\delta^{18} O_{G \text { ruber }}$ en se focalisant sur la dernière déglaciation. Le modèle d'âge a été établi à l'aide du logiciel Oxcal (Bronk Ramsey, 1995, 2001; Reimer et al., 2004). Les triangles représentent les niveaux datés au ${ }^{14} \mathrm{C}$. 


\begin{tabular}{|c|c|c|c|c|}
\hline Depth $(\mathrm{cm})$ & Sample code & Material & $\begin{array}{c}\text { AMS }{ }^{14} \mathrm{C} \text { age }\left({ }^{14} \mathrm{C}\right. \\
\text { yr BP })\end{array}$ & $\begin{array}{l}\text { Oxcal calibrated } \\
\text { age (Cal yr BP) }\end{array}$ \\
\hline 5 & MD92-1002/ I-5 cm & G. ruber & $820 \pm 30$ & $303 \pm 96$ \\
\hline 39.5 & MD92-1002/ I-39.5 cm & G. ruber, G. sacculifer & $1045 \pm 40$ & $498 \pm 75$ \\
\hline 152 & MD92-1002/ II-3 cm & G. ruber & $3015 \pm 30$ & $2594 \pm 105$ \\
\hline 221.5 & MD92-1002/ II-72.5 cm & G. ruber & $4235 \pm 30$ & $4110 \pm 118$ \\
\hline 306.5 & MD92-1002/III-7.5 cm & G. ruber & $6265 \pm 35$ & $6530 \pm 96$ \\
\hline 407.5 & MD92-1002/III- $108.5 \mathrm{~cm}$ & G. ruber & $9475 \pm 40$ & $10135 \pm 121$ \\
\hline 507.5 & MD92-1002/IV-57.75 cm & G. ruber & $10450 \pm 40$ & $11315 \pm 155$ \\
\hline 622.75 & MD92-1002/ V-22.75 cm & G. ruber & $11760 \pm 45$ & $13074 \pm 108$ \\
\hline 677.5 & MD92-1002/V-77.5 cm & G. ruber, G. sacculifer & $13000 \pm 50$ & $14558 \pm 233$ \\
\hline 834 & MD92-1002/VI-84 cm & G. ruber, G. sacculifer & $14910 \pm 60$ & $17474 \pm 148$ \\
\hline
\end{tabular}

Tab. 1: Radiocarbon ages and the corresponding calendar ages for the marine core MD92-1002.

Tab. 1 : Les âges radiocarbone et les âges calendaires correspondants obtenus pour la carotte MD92-1002.

tation rates vary from a minimum of $\sim 28 \mathrm{~cm} / \mathrm{ka}$ between 10,000 and 6,500 cal. yr BP to a maximum of $\sim 85 \mathrm{~cm} / \mathrm{ka}$ between 10,000 and 11,000 cal. yr. BP.

\section{2 - PALYNOLOGICAL RECORDS}

Ninety-five samples were collected from core MD921002 for this study. Temporal resolution was enhanced in the interval corresponding to the last deglaciation (sampling rate: $6 \mathrm{~cm}$ ). Samples were successively attacked with cold hydrochloric acid ( $\mathrm{HCl}, 10 \%)$ and cold hydrofluoric acid (HF, $70 \%$ ) in order to remove the carbonate and silicate fractions (Fægri \& Iversen, 1975). However, because samples were particularly rich in organic matter (up to $3 \%$ in the Holocene, see Bouilloux et al., 2013a), we had to proceed with a brief $(<10 \mathrm{mn})$ addition of potassium hydroxide $(10 \% \mathrm{KOH})$ in order to deflocculate the organic matter just prior to sieving at $5 \mu \mathrm{m}$. The potential risk of damaging palynomorphs was clearly balanced by the need to extract them efficiently. Pollen and spore counts were used for the reconstruction of the continental hydrology over the Southern Arabia and the Horn of Africa (Fersi et al., in press). In this paper, we focus on the marine components of the organic micro-remains: copepod eggs and dinoflagellate cysts. Tintinnids and arthropod fragments were in very low abundance and scattered occurrence and thus are not discussed here. Percentages of copepod eggs were calculated against the sum of total marine micro-remains counted excluding undeterminable ones whereas dinoflagellate cyst $\%$ were calculated against the sum of all the dinoflagellate cysts.

\section{3 - ORGANIC CARBON CONTENT AND XRF- DERIVED BROMINE}

Total Organic Carbon (TOC in \%) had been measured on 65 samples using a LECO C-S 125 elemental combustion analyzer (uncertainties $<0.1 \%$; Ouahdi, 1997). For the present study, we reconstructed qualitatively the relative contribution of Bromine (Br), which has been shown to co-vary with organic content in sediments of Arabian Sea (Ziegler et al., 2008). High-resolution bromine variations were derived from XRF-scanning performed on U-channels using an Avaatech XRF core scanner at EPOC laboratory (Bordeaux, France). Measurements were obtained at $1 \mathrm{~cm}$ resolution with ionization energy of $30 \mathrm{kV}$.

\section{3 - RESULTS}

A total of thirty taxa of organic-walled dinoflagellate cysts were identified. Cyst taxonomy follows Fensome and Williams (2004) and the most updated classification of Fensome et al (2008) (table 2). Total counts averaged about 334 cysts/sample, although several samples contained much smaller amounts of dinocysts $(<80-100)$. Data are represented in a form of percentage diagram using Tilia 2.0 software (Grimm et al., 1993) in figure 3. All counts are listed in Appendix. Two main groups can be distinguished:

- The Gonyaulacoid autotrophic taxa is the group that dominates the assemblages. They are mainly represented by Spiniferites and include Spiniferites ramosus $($ mean $=34.7 \%)$, Spiniferites pachydermus $($ mean $=13.8 \%)$, Spiniferites bulloideus $($ mean $=9.5 \%)$, Spiniferites bentorii (mean $=4.3 \%$ ) and Spiniferites mirabilis associated with Bitectatodinium spongium (mean $=9.7 \%$ ), Polysphaeridium zoharyi (mean $=7.8 \%$ ), Impagidinium spp. (Impagidinium paradoxum, Impagidinium patulum and Impagidinium sphaericum), Operculodinium spp. (Operculodinium centrocarpum and Operculodinium israelianum), Linguodinium machaerophorum and Tuberculodinium vancampoae.

- Heterotrophic taxa are much less abundant, averaging only a few percents. They correspond to the Protoperidinium group including Echinidinium spp. (Echinidinium aculeatum, Echinidinium delicatum, Echinidinium granulatum and Echinidinium transparantum), Selenopemphix quanta and additional rare taxa (Brigantedinium spp., Trinovantedinium applanatum, Trinovantedinium spp., Votadinium calvum and Votadinium spp.). 


\begin{tabular}{|l|l|}
\hline \multicolumn{1}{|c|}{$\begin{array}{l}\text { Dinoflagellate cysts } \\
\text { (paleontological name) }\end{array}$} & \multicolumn{1}{|c|}{$\begin{array}{c}\text { Thecate dinoflagellate affinity } \\
\text { (Biological name) }\end{array}$} \\
\hline Gonyaulaceae family & \\
\hline Ataxiodinium choane & Gonyaulax sp. inlet. \\
\hline Bitectatodinium spongium & unknown \\
\hline Impagidinium paradoxum & Gonyaulax sp. inlet. \\
\hline Impagidinium patulum & Gonyaulax sp. inlet. \\
\hline Impagidinium aculeatum & Gonyaulax sp. inlet. \\
\hline Impagidinium sphaericum & Gonyaulax sp. inlet. \\
\hline Lingulodinium machaerophorum & Lingulodinium polyedrum \\
\hline Nematosphaeropsis labyrinthus & Gonyaulax spinifera complex \\
\hline Operculodinium centrocarpum & Protoceratium reticulatum \\
\hline Operculodinium israelianum & Protoceratium reticulatum \\
\hline Polysphaeridium zoharyi & Pyrodinium bahamense \\
\hline Spiniferites bulloideus & Gonyaulax scrippsae \\
\hline Spiniferites mirabilis & Gonyaulax spinifera complex \\
\hline Spiniferites ramosus & Gonyaulax spinifera complex \\
\hline Spiniferites bentorii & Gonyaulax digitalis \\
\hline Spiniferites spp. & Gonyaulax sp. inlet \\
\hline Spiniferites pachydermus & Gonyaulax sp. inlet \\
\hline Peridiniaceae family & \\
\hline Brigantedinium spp. & Protoperidinium sp. \\
\hline Echinidinium aculeatum & unknown \\
\hline Echinidinium delicatum & unknown \\
\hline Echinidinium granulatum & unknown \\
\hline Echinidinium transparantum & unknown \\
\hline Echinidinium spp. & unknown \\
\hline Pentapharsodinium dalei & Ensiculifera imariense \\
\hline Selenopemphix quanta & Protoperidinium conicum \\
\hline Trinovantedinium applanatum & Protoperidinium pentagonum \\
\hline Trinovantedinium spp. & Protoperidinium sp. \\
\hline Votadinium spp. & Protoperidinium sp. \\
\hline Votadinium calvum & Protoperidinium oblongum \\
\hline Pyrophacaceae family & \\
\hline Tuberculodinium vancampoae & Pyrophacus steinii \\
\hline
\end{tabular}

Tab. 2: List of dioflagellate cyst taxa identified in sediment samples from the core MD92-1002 with their motile equivalent.

Tab. 2 : Liste des taxons de kystes de dinoflagellés identifiés dans les échantillons de sédiment de la carotte MD92-1002 et liste de leurs équivalents mobiles.

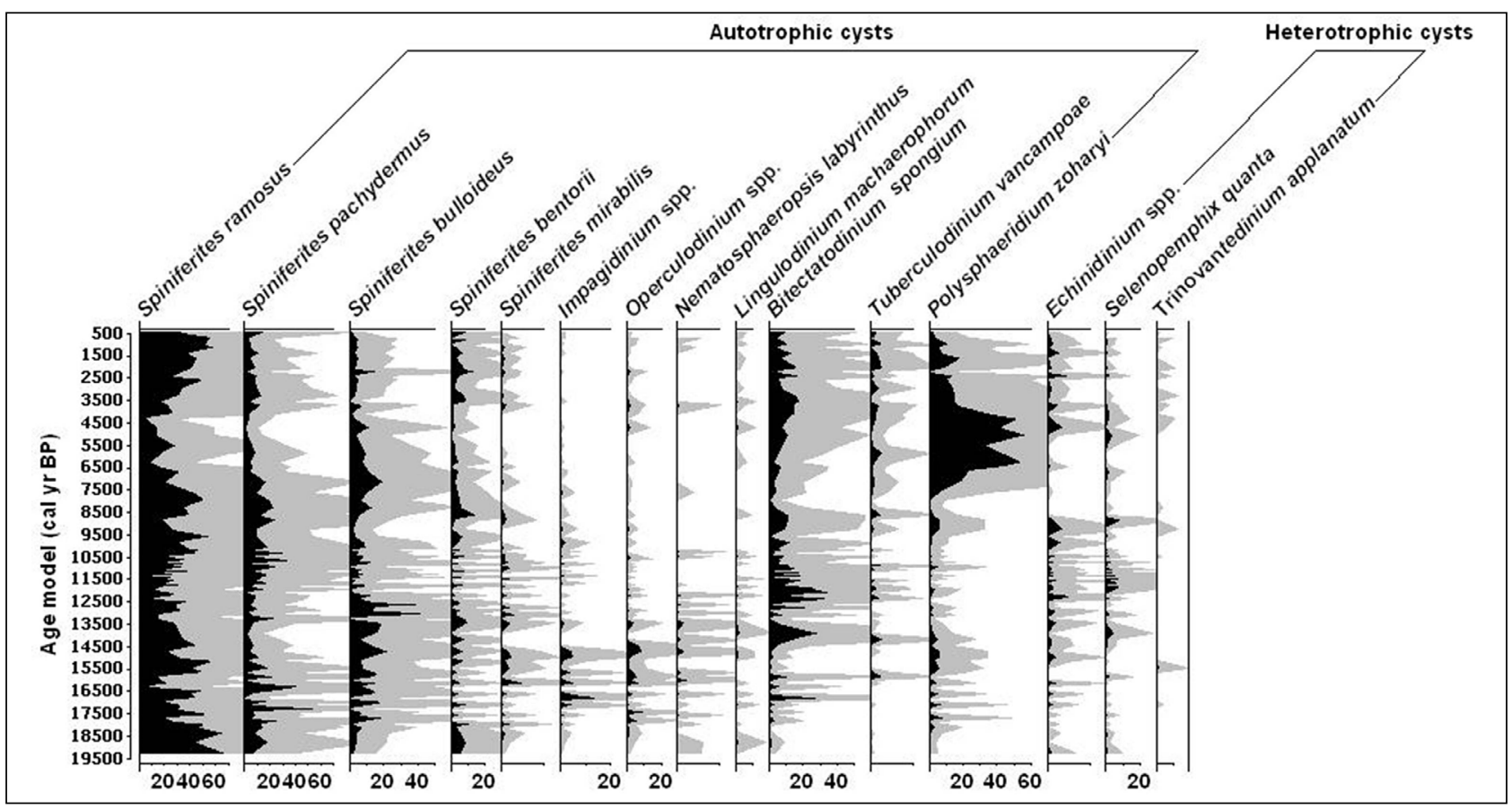

Fig. 3: Synthetic diagram representing relative abundances $(\%)$ of autotrophic and heterotrophic dinoflagellate cysts taxa versus calendar age. Fig. 3 : Diagramme synthétique représentant l'abondance relative (\%) des taxons de kystes de dinoflagellés autotrophes et hétérotrophes en fonction des âges calendaires. 
In order to facilitate the interpretation of dinoflagellate cysts and emphasize common variance between taxa, we performed a hierarchical clustering analysis using the R software (Ihaka \& Gentleman, 1996). This clustering uses correspondence analysis factors to derive a classification-tree of taxa and a partition of these taxa into homogeneous clusters. We interpreted this partition based on the environmental significance of dinoflagellate species deduced from the spatial distribution of dinoflagellate cysts in surface sediments from the western Arabian Sea (Abidi, 1997; Zonneveld, 1997; Zonneveld \& Brummer, 2000).

The hierarchical clustering analysis resulted in 6 clusters (fig. 4A):
- Cluster 1 contains two species: N. labyrinthus and S. bulloideus;

- Cluster 2 contains three species: S. ramosus (the dominant species) and, to a lesser extent, $S$. bentorii and E. aculeatum;

- Cluster 3 contains various Impagidinium and Operculodinium species, cysts of $P$. dalei, S. mirabilis, L. machaerophorum and E. granulatum;

- Cluster 4 contains S. pachydermus and Spiniferites spp.;

- Cluster 5 contains B. spongium, T. vancampoae, E. delicatum, E. transparantum, Votadinium spp., Trinovantedinium spp. and S. quanta;

- Cluster 6 contains a single species: P. zoharyi.

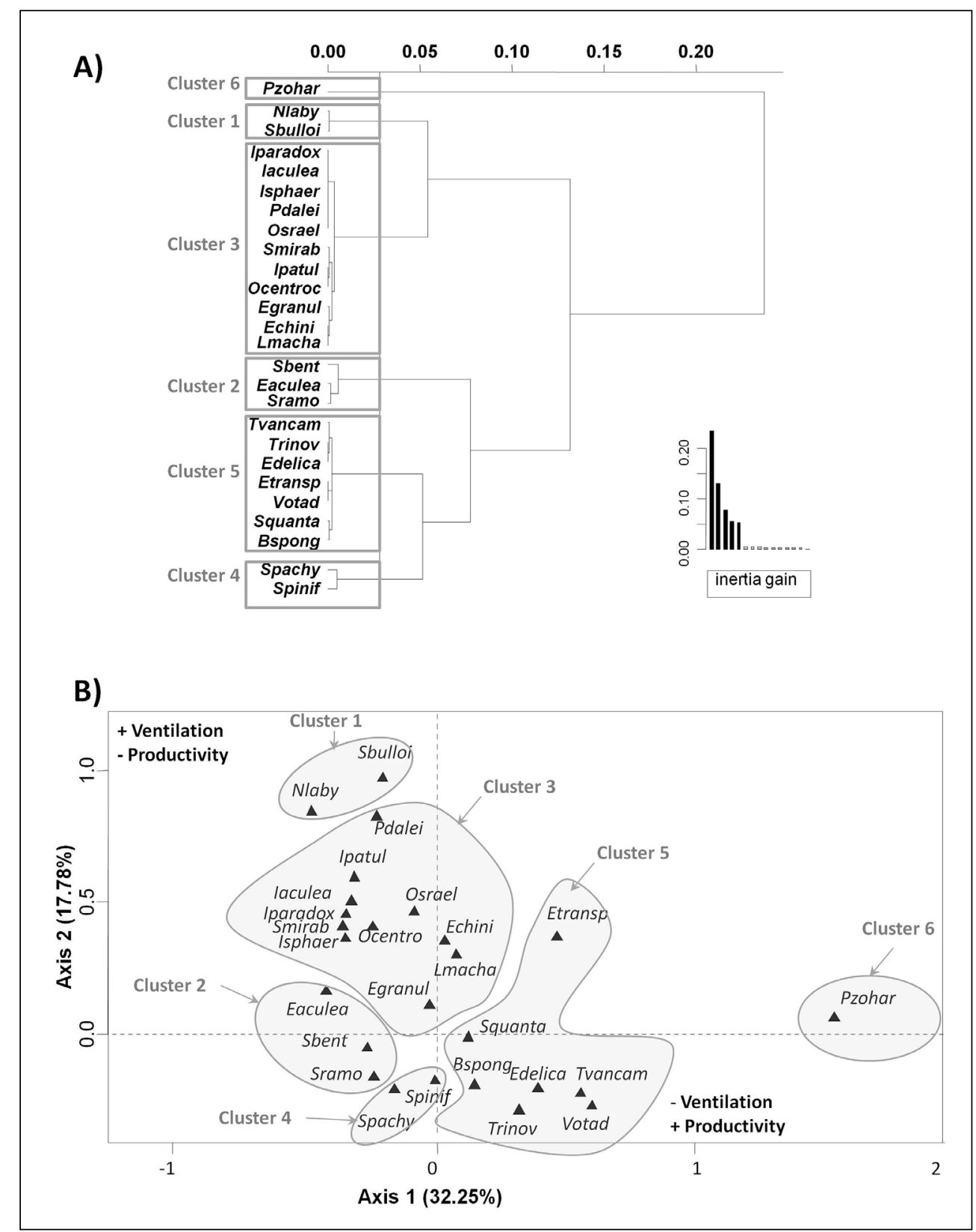

Fig. 4: Statistical analyses of dinoflagellate cyst taxa from the core MD92-1002.

A/ Hierarchical Clustering Analysis obtained on dinoflagellate cyst taxa. B/ Distribution pattern, on the first factorial plan (axis 1 vs. axis 2 ) of dinoflagellate cyst clusters.

Fig. 4 : Analyses statistiques réalisées sur les taxons de kystes de dinoflagellés de la carotte MD92-1002. A/ Classification Ascendante Hiérarchique des taxons de kystes de dinoflagellés. B/Projection des groupes de kystes de dinoflagellés sur le premier plan factoriel (axe 1 vs. axe 2). 
A multivariate statistical factor analysis (AFC) was performed on the relative abundance of dinoflagellate cysts (fig. 4B). Five principal axes were determined accounting for $32 \%, 18 \%, 10.4 \%, 7 \%$ and $5.8 \%$ of the total variance respectively (total cumulative variance is $73 \%$ ). The projection of clusters on the plane determined by the first most dominant two axes shows that clusters 1 and 3 (positive side) are clearly separated from $S$. ramosus, cluster 4 and most species from cluster 5 . Along the principal axis 1 , cluster 6 (P. zoharyi) is clearly separated from all the other clusters. Cluster 6 (P. zoharyi) explains nearly $60 \%$ of the total dinoflagellate abundance during the mid-Holocene (fig. 3), but is only weakly represented (few percent) across the last deglaciation and during the early Holocene climatic optimum.

To help us reconstruct the time-dependent evolution of dinoflagellate cysts along core MD92-1002, we plotted on figure 5, the evolution of the three clusters that explain the largest proportion of variance in the interval from the last glacial maximum to the Holocene climatic optimum (i.e. clusters 2, 3 and 5). We also plotted the oxygen isotope record as a stratigraphic reference, as well as the relative percentage of copepod eggs. Cluster 2 is represented mainly by the autotrophic taxon $S$. ramosus, which dominates the dinoflagellate cyst assemblages. This taxon exhibits high percentages (up to $40 \%$ ) during the LGM, between 10 and $8 \mathrm{ka}$, then during the Late Holocene. Minimum values are recorded between 6 to $4 \mathrm{ka}$. Cluster 3 displays its maximum contribution from $18 \mathrm{ka}$ to the beginning of the deglacial period, at about $14.2 \mathrm{ka}$ and decreases significantly upward. Cluster 5 shows low values during the glacial period except for the short peak at $\sim 16.7 \mathrm{ka}$. The value of this cluster increases from $14.4 \mathrm{ka}$ and

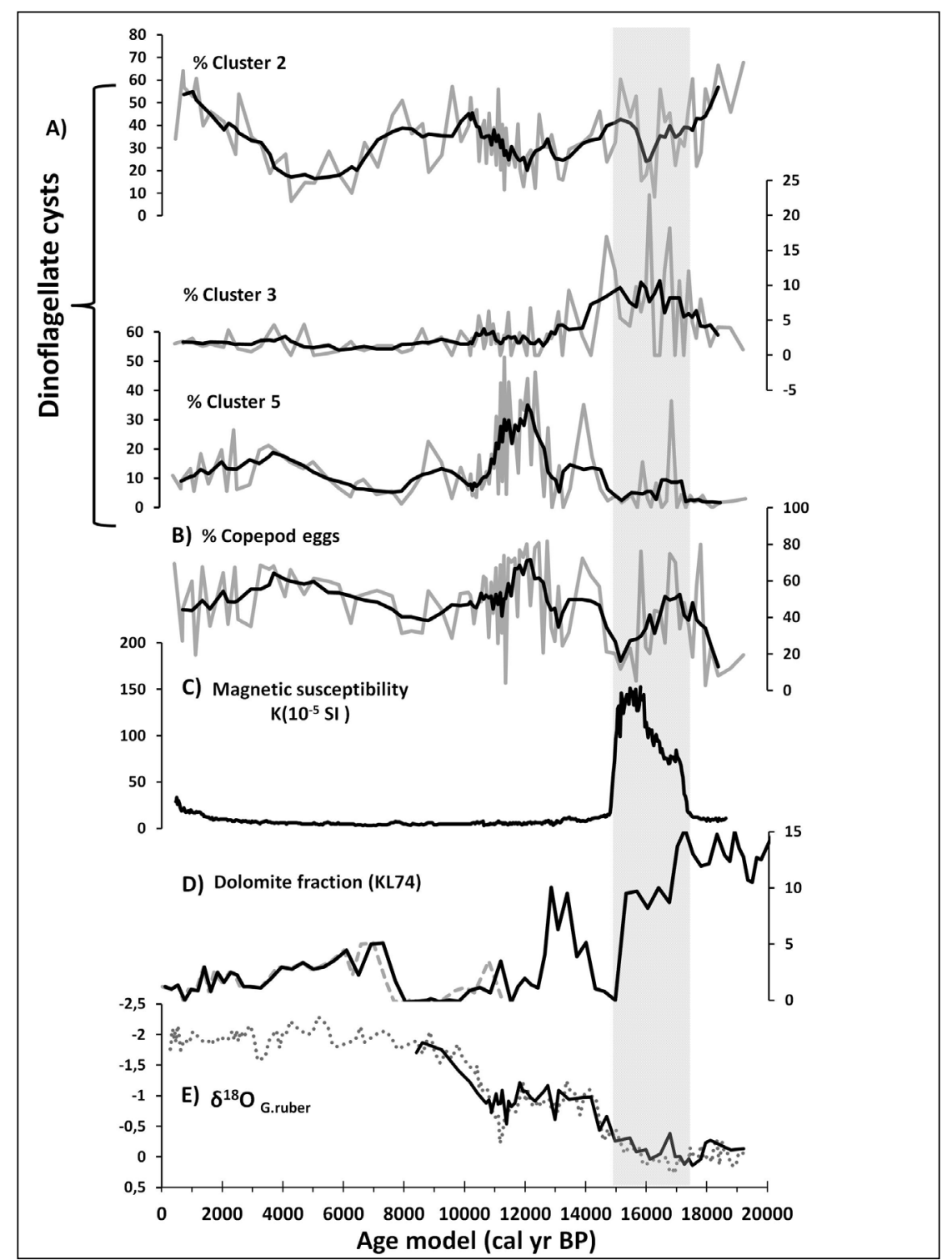

Fig. 5: Variations of dinoflagellate cyst clusters along core MD92-1002 compared with the evolution of other paleoenvironmental proxies. A/ Temporal variations of principal dinoflagellate cyst clusters (cluster 2, cluster 3 and cluster 5). B/ Changes of copepod abundance. C/ MD92-1002 core profile of magnetic susceptibility (Bouilloux et al., 2013a). D/ Dolomite record from the core KL74 (Sirocko et al., 1993). E/ Isotopic stratigraphy. The grey interval corresponds to the peak of the magnetic susceptibility peak.

Fig. 5 : Variations des groupes de kystes de dinoflagellés le long de la carotte MD92-1002 comparées avec l'évolution d'autres traceurs paléoenvironnementaux. A/Variations temporelles des principaux groupes de kystes de dinoflagellés (groupe 2, groupe 3 et groupe 5). B/ Changements de l'abondance en copépodes. C/ Courbe de susceptibilité magnétique de la carotte MD92-1002 (Bouilloux et al., 2013a). D/Variations de la dolomite dans la carotte KL74 (Sirocko et al., 1993). E/ Stratigraphie isotopique. L'intervalle surligné en gris correspond au pic de susceptibilité magnétique. 
reaches its maximum between 12.6 and $10.8 \mathrm{ka}$. The relative contribution of cluster 5 declines during the early and mid-Holocene and increases again in the late Holocene, after $5 \mathrm{ka}$. As can be readily seen on figure 5 , the relative abundance of copepod eggs shows a very good correlation with cluster 5 oscillations.

\section{4 - DISCUSSION}

\section{1 - PALEO-ENVIRONMENTAL INTERPRETATION OF DINOFLAGELLATE CYST ASSEMBLAGES}

Dinoflagellate cyst distribution is strongly related to physico-chemical characteristics of surface waters, such as temperature, salinity and nutrient content (e.g. Marret, 1994; Matthiessen, 1995; Zonneveld, 1996; de Vernal \& Pedersen, 1997; Marret \& de Vernal, 1997; Zonneveld et al., 1997a,b; Zonneveld \& Brummer, 2000; de Vernal et al., 2001, 2005; Radi et al., 2001; Elshanawany \& Zonneveld, 2016). Thus, organic-walled dinoflagellate cysts have been extensively used to reconstruct paleoenvironmental and paleoceanographic conditions (deVernal \& Hillaire-Marcel, 1987; Marret \& Turon, 1994; Versteegh \& Zonneveld, 1994; Versteegh et al., 1996; Zonneveld et al., 1997a,b; Zonneveld \& Brummer, 2000; Mudie et al., 2002; Marret \& Zonneveld, 2003; Pospelova et al; 2006).

Cluster 2 is dominated by $S$. ramosus. The environmental significance of this taxon in our record is not straightforward since it is a cosmopolitan species, which shows a broad geographic distribution, from sub-polar to equatorial (Zonneveld et al., 2013). It dominates the dinocyst assemblages offshore Yemen and it is observed in many upwelling areas in the Arabian Sea (Zonneveld et al., 1997b), the Gulf of Guinea (Marret, 1994) and off South Africa (Davey \& Rogers, 1975). However, S. ramosus is also found in weak upwelling areas (Lewis et al., 1990) and oligotrophic environments such as the northern Red Sea and the Gulf of Aqaba (Elshanawany \& Zonneveld, 2016). In the Somalia region, its highest abundance occurs at the end of the SW monsoon, when water masses are relatively stable, with high nutrient concentrations (Zonneveld \& Brummer, 2000). This suggests that $S$. ramosus is characteristic of eutrophic, productive areas, but is not necessarily associated to intense upwelling conditions (Abidi, 1997). In core MD92-1002, the high values reached by cluster 2 during the glacial interval would indicate, therefore, that summer productivity was high but not necessarily associated to strong upwellings. This is confirmed by the fact that dinoflagellate species characteristic of more intense summer monsoon upwelling conditions are grouped within cluster 5 , which shows a maximum during the deglaciation, when cluster $2 \mathrm{had}$ already started to decline.

The main contributors of cluster 3 are Impagidinium spp. and Operculodinium spp. Today, Impagidinium associated with Nematosphaeropsis are produced during non-upwelling seasons (Zonneveld \& Brummer, 2000; Zonneveld et al., 2013). The two additional contributors of cluster 3 S. mirabilis and L. machaerophorum, are most abundant at the transition between the SW-NE monsoon (Zonneveld et al, 1997b; Zonneveld \& Brummer, 2000; Zonneveld et al., 2013), when stratified upper waters develop. Most importantly, both Impagidinium and Operculodinium are known to be particularly resistant to oxidative degradation (especially Impagidinium), and their relative abundance compared to other more fragile dinoflagellates is high in sediments from open marine sites where bottom waters are well ventilated (Abidi, 1997; Zonneveld et al., 2013; Zonneveld \& Brummer, 2000). Thus, high values of cluster 3 could suggest that relatively well ventilated bottom water conditions prevailed between 18 and $14.2 \mathrm{ka}$, and declined afterwards. This is in good accordance with changes in magnetic mineralogy along core MD92-1002. The maximum in cluster 3 corresponds to an interval characterized by much higher magnetic susceptibility than along the rest of the core (fig. 5). Bouilloux et al. (2013a) showed that this high amplitude susceptibility results from a switch between a magnetite-goethite assemblage, which dominates magnetic mineralogy in most of core MD92-1002, to a purely magnetite-dominated assemblage within the high susceptibility peak. These authors suggested that most of the initial magnetite had been lost through reductive processes in core MD92-1002, except in this highsusceptibility peak, which they interpreted as resulting from a low productivity episode and/or an episode of OMZ breakdown associated to the northward extension of well oxygenated intermediate waters (Bouilloux et al., 2013a). The high values of cluster 3 , which we interpret as an indication of well-ventilated bottom waters, appear to support the second hypothesis.

B. spongium and Protoperidinium cysts (dominated by $S$. quanta) are the main contributors of cluster 5 , which displays a maximum during the deglaciation in core MD92-1002. Today, these dinoflagellates develop mostly during the SW monsoon in the upwelling off Somalia where they constitute about $30-40 \%$ of the total assemblages collected in sediment traps (Zonneveld et al., 1997a; Zonneveld \& Brummer, 2000). Outside upwelling areas, $B$. spongium is found in eutrophic surface waters with high primary productivity. Protoperidinium cysts are also sensitive to aerobic decay and is particularly abundant in sediments lying beneath very high productivity waters and bathed by poorly ventilated bottom water. Thus, in the Arabian Sea, Protoperidinium cysts abundance has been used as a proxy to reconstruct past OMZ variations associated to peak in productivity resulting from intense summer monsoon upwellings (Zonneveld et al., 1997b, 2007, 2013; Reichart \& Brinkhuis, 2003; Narale et al., 2015). Based on these pieces of evidence, we interpret cluster 5 as reflecting the intensity of upwelling in the Gulf of Aden. This conclusion is strengthened by the remarkable correlation between cluster 5 and the abundance of copepod eggs (fig. 5). Our data suggest therefore that upwelling in the Gulf of Aden were particularly active during the interval between 12.6 and $10.8 \mathrm{ka}$ with a peak intensity at about $12 \mathrm{ka}$. 
Cluster 5 declines in the Holocene. The mid-Holocene period is primarily characterized by the occurrence of P. zoharyi, which dominates the assemblage and represents up to $50 \%$ between 4 and $6 \mathrm{ka} \mathrm{BP}$ (fig. 3). In the modern ocean, this taxon is found within a broad salinity range between 16.2 and $36.6 \%$, in water with relatively low nutrient contents (Zonneveld et al., 2013). Because of its tolerance to extreme salinities, it occurs in salty lagoonal environments (Marret \& Zonneveld, 2003) and in the hyper saline surface waters of the Red Sea (Wall et al., 1977). Today, the occurrence of P. zoharyi in the Gulf of Aden seems to be related either (i) to outspilling of surface water from the Red Sea during the summer season, when NW winds blow along the Red Sea axis and push water towards the Bab-al-Mandab strait, or (ii) to the exit of Red Sea intermediate waters (Zonneveld, 1997).

\section{2 - SEQUENCE OF EVENTS ACROSS THE LAST DEGLACIATION IN CORE MD92-1002}

The primary productivity was already high in the Gulf of Aden during the LGM, as shown by the high values of cluster 2, which contains dinocyst taxa typical of eutrophic waters. Nevertheless, intensity of seasonal upwellings was weak as revealed by low values of cluster 5 , from the bottom of the core up to $14.9 \mathrm{ka}$. The only short interval where cluster 5 shows high values is between 17 and $16.4 \mathrm{ka}$, coeval with higher abundances of copepod eggs (fig. 5). Within the uncertainties of our age model, this time interval is coeval with Heinrich 1 (Hemming, 2004), and may suggest a response of low latitude wind intensity to remote changes occurring at high, northern latitudes. But this hypothesis will need to be tested in future works. The resolution of our micropaleontological analyses is not sufficient across this interval and the record shows a too high variability to conclude confidently about the potential impact of $\mathrm{H} 1$ at the core site. Neither the low resolution TOC record nor the higherresolution $\mathrm{Br}$ record, suggest any clear change in organic matter burial over the time interval corresponding to $\mathrm{H} 1$.

The overall low intensity of upwellings in the Gulf of Aden during the last glacial period is coherent with several paleoclimatic reconstructions and climatic models, which suggest weakened summer monsoonal-wind over the Arabian Sea (Prell \& Kutzbach, 1987; Sirocko et al., 1991; Naidu \& Malmgren, 1996; Caley et al., 2011). Low intensity of upwelling system in the Gulf of Aden has apparently been associated to reduced OMZ and a relatively good ventilation of bottom waters at the site of MD92-1002, explaining high values of cluster 3 from $\sim 18$ to $\sim 14.2 \mathrm{ka}$. As seen above, the peak in cluster 3 corresponds to an interval characterized by very high magnetic susceptibility resulting from the preservation of magnetite. Bouilloux et al. (2013a) interpreted this peak of magnetite as reflecting (i) changes in redox conditions at the seafloor in response to lower surface productivity and/or (ii) enhanced ventilation of intermediate waters through the northward extension of Glacial Antarctic Intermediate Water (GAAIW) into the Arabian Sea (Jung et al., 2009).
The first clear post-glacial increase in productivity resulting from an intensification of upwellings took place around $14.5 \mathrm{ka} \mathrm{BP}$, as shown by the rise in cluster 5 . It is associated with a decline in cluster 3 , which suggests a decrease of oxygenation and the development of the OMZ. Interestingly, this increase in productivity follows the onset of the post-glacial humidity increase over the Horn of Africa and Arabia, which took place at 14.68$14.5 \mathrm{ka}$ as revealed by several paleohydrological and paleoclimatic reconstructions based on East African lakes (e.g. Foerster et al., 2012; Tierney \& deMenocal, 2013) and speleothems from Socotra (Shakun et al., 2007; Van Rampelbergh et al., 2013). This increase in humidity has been interpreted as reflecting the first evidence of a progressive northward and westward displacement of the summer position of the Inter Tropical Convergence Zone (ITCZ), which occurred over the last deglaciation in response to the increase in boreal summer insolation (Fersi et al., in press). Cluster 5 shows a short interval of low values between $\sim 13.5$ and $\sim 12.5 \mathrm{ka}$, which could be interpreted as a decrease in upwelling intensity and, thus, a weakening of wind forcing. Within the uncertainty of our age model, this interval is coeval with an interval of higher dolomite content in marine core KL74 (off the coast of Oman), which traduces an increase in the efficiency of eolian dust transport (Sirocko et al., 1993; fig. 5D). The fact that dolomite supply was enhanced at a time of potentially weakened wind activity suggests that eolian dust transport efficiency was mostly controlled by humidity/aridity. This hypothesis is confirmed by pollen analysis of the core MD92-1002, which reveals a decrease in humidity over this time interval (Fersi et al., in press). After $12.5 \mathrm{ka}$, upwelling intensity increased as shown by the increase in cluster 5 .

Our data suggest that primary productivity and upwelling intensity declined during the early Holocene, as shown by the progressive drop in cluster 5 from $10.8 \mathrm{ka}$ onward. This result apparently conflicts with paleo-reconstructions of upwelling intensity off the Oman coast, which suggest that SW monsoon wind forcing and intensity of summer upwelling increased in connection with the increase of northern boreal summer insolation, which reached a peak at $\sim 9 \mathrm{ka}$ (Gupta et al., 2003, 2011). As we have seen above, the Gulf of Aden is landlocked between Arabia and Somalia and is located at the junction between two nearly orthogonal wind regimes during the summer season due to the position of the ITCZ: (i) the strong and well known SW monsoon winds that control seasonal upwellings along the Arabia and Somalia coasts, to the east, and (ii) NW winds blowing along the main axis of the Red Sea, to the west. We assume that the complex interplay of these two wind systems and their relative intensity evolution through time in response to insolation forcing and the spatial wandering of the ITCZ explained that productivity and upwelling intensity peaked in the Gulf of Aden during the deglaciation, and decreased during the early Holocene, when upwelling intensity reached a peak along the Oman margin. Such an assumption will be tested in collaboration with past climate modelers. 
Finally, as seen above, $P$. zoharyi dominates the dinocyst assemblages and represents up to $50 \%$ in the interval from 4 to $6 \mathrm{ka}$. The dominant contribution of $P$. zoharyi could suggest that this time period was characterized by increased, seasonal spilling out of surface or sub-surface waters from the Red Sea towards the Gulf of Aden. This could have been associated with the intensification of summer winds blowing from the NW along the Red Sea, and pushing surface waters towards the Gulf of Aden during the summer season. Such a hypothesis will be tested in future work including data/model comparison exercises.

\section{3 - FACTORS CONTROLLING THE ORGANIC CARBON PRODUCTION IN THE GULF OF ADEN}

The bromine content of core MD92-1002 derived from XRF scanning is perfectly correlated with the TOC record (fig. $6 \mathrm{C}$ and $\mathrm{D}$ ), suggesting that bromine content in sediments from the Gulf of Aden is directly related to the organic matter imbedded in the sediments. Ouahdi (1997) discussed the origin of the organic matter in our core site. This author excluded a continental origin due to the low fresh water runoffs from arid adjacent continents bordering the Gulf of Aden. She concluded that marine

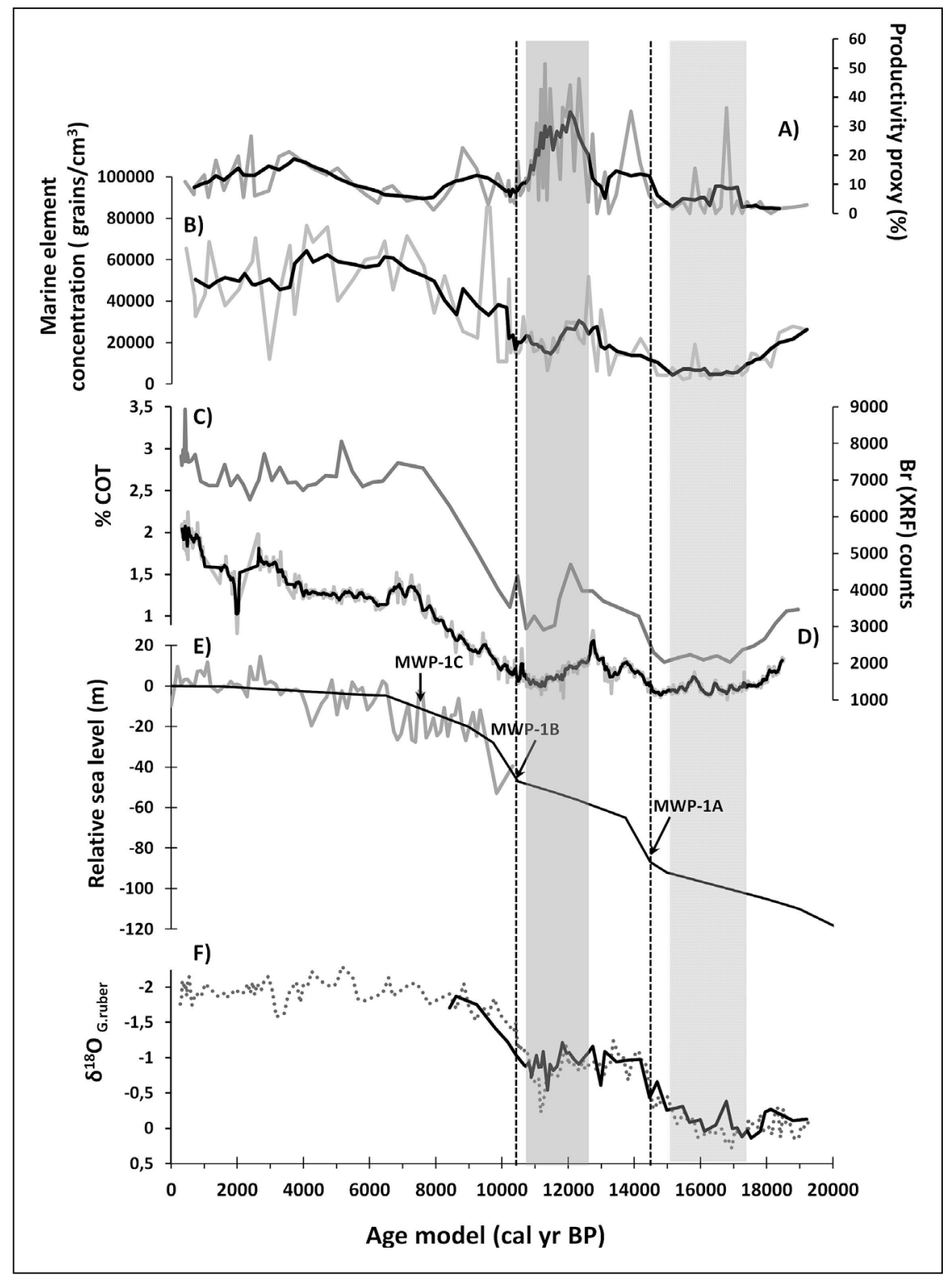

Fig. 6: Productivity proxies and organic matter content in core MD92-1002; evolution of paleoproductivity and organic carbon preservation from 20 ka to the present in the Gulf of Aden.

A/ Cluster 5 (marine productivity proxy). B/ Total micropaleontological marine elements abundance. C/ TOC profile. D/ XRF-derived bromine profile. E/ Relative sea level variations during the last 20 ka (Fleming \& Lambeck, 1998; Siddall et al., 2003). F/ Isotopic stratigraphy of core MD92-1002. The period representing the maximum of surface productivity is figured by a grey band and the period of maximum magnetite preservation, after Bouilloux et al. (2013a), is represented by a shaded band.

Fig. 6: Indicateurs de productivité et teneurs en matière organique dans la carotte MD92-1002 : évolution de la paléoproductivité et de la préservation du carbone organique depuis $20 \mathrm{ka}$ dans le Golfe d'Aden. A/ Groupe 5 (indicateur de productivité marine). B/Concentration totale en éléments micropaléontologiques marins. C/ Courbe du Carbone Organique Total. D/Courbe du brome obtenue par XRF. E/Variation relative du niveau marin pendant les derniers 20000 ans (Fleming \& Lambeck, 1998; Siddall et al., 2003). F/ Stratigraphie isotopique de la carotte MD92-1002. Le maximum de productivité de surface est représenté par une bande grise et la période de préservation de la magnétite, d'après Bouilloux et al. (2013a), est figurée par une bande hachurée. 
surface productivity and preservation at the sea floor were the principal factors controlling organic matter content in the sediment from the Gulf of Aden (Ouahdi, 1997). TOC and $\mathrm{Br}$ curves are well correlated and resemble closely the total concentration of marine planktonic organisms (fig. 6B). Surprisingly, they do not mimic changes in primary productivity revealed by variations of dinocyst assemblages or copepod egg contents. While maximum upwelling intensity and biological productivity are reconstructed between 12.6 and $10.8 \mathrm{ka}$ (fig 6A), TOC and $\mathrm{Br}$ evolve in a stepwise way since the last glacial period and reached their maximal values around 7.6 and $7.2 \mathrm{ka}$, respectively.

The stepwise evolutions of $\mathrm{Br}$ and TOC records are well correlated with the $\delta^{18} \mathrm{O}$ record of MD92-1002 (fig. 6F) and glacio-eustatic sea level changes (fig. $6 \mathrm{E}$, Fleming \& Lambeck, 1998; Siddall et al., 2003). Increase in Br and TOC follow the two periods of sea level rise; Meltwater pulses 1A (Fairbanks, 1989; Bard et al., 1996) and 1B (Fairbanks, 1989) at 14.6 and $10.5 \mathrm{ka}$, respectively. The maximum development of upwelling intensity (peak of cluster 5), occurred during a phase of relative stability of the sea level.

The fact that TOC and $\mathrm{Br}$, which are indicative of the amount of organic matter within the sediments, are clearly decoupled from variations in dinoflagellate cyst assemblages and do not correspond to the maximum of our index of upwelling intensity suggests that TOC content at the core location mostly reflect changes in preservation at the sea floor rather than primary productivity. The close resemblance between the sea level record and the $\mathrm{Br}$ and TOC records of MD92-1002 is puzzling. This could indicate that the preservation of organic matter in the Gulf of Aden is associated somehow to changes in the amount and/or characteristics of salty and poorly oxygenated intermediate waters that are expelled from the Red Sea, in relation to change in the eustatic level and the depth of the Bab-el-Mandab Strait.

Interestingly, off the coast of Somalia, the benthic $\delta^{13} \mathrm{C}$ record of core NIOP905 does not show such a strong glacial/interglacial signature but reveals millennial-scale changes of deep-sea ventilation in response to circulation pattern driven at high latitudes (Jung et al., 2009). One of these rapid changes in benthic $\delta^{13} \mathrm{C}$, synchronous with Heinrich 1 event, is coeval with the magnetic susceptibility peak in core MD92-1002 (Bouilloux et al., 2013a). However, other oscillations in the NIOP905 benthic $\delta^{13} \mathrm{C}$ records are not mimicked in the mineralogy and/or organic content of core MD92-1002. This clearly underlines the complexity of organic matter preservation at regional scale in the area of the western Arabian Sea.

As far as surface conditions are concerned, a previous study had suggested that changes in the rate of sea level rise during glacial terminations could significantly affect surface salinities outside the Red Sea (Malaizé et al., 2009). As seen above, however, it is during the midHolocene that $P$. zoharyi became the dominant species, an increase that we interpret as reflecting the enhanced out-spilling of high-salinity surface or intermediate water from the Red Sea under the control of atmospheric circulation. Additional studies are mandatory to decipher more clearly the impact of water exchanges between the Red Sea and the Gulf of Aden on sea surface conditions and faunal changes. We have recently started a research project dealing with the estimation of past surface salinities based on the combination of planktonic foraminifer $\delta^{18} \mathrm{O}$ with $\mathrm{Mg} / \mathrm{Ca}$ paleo-temperature proxy.

\section{5 - CONCLUSIONS}

Based on our dinocyst and organic matter analyses we suggest that bottom water was well oxygenated from the LGM to $14.2 \mathrm{ka}$, with an event of particularly strong ventilation which induced the good preservation of magnetite and resulted in a clear peak in magnetic susceptibility (Bouilloux et al., 2013a). Surface productivity during the glacial termination was high but not as high as during the deglaciation. Increase in productivity during the deglaciation was coeval with the first evidence of humidity increase associated to the onset of the Holocene Humid Period (Shakun et al., 2007; Foerster et al., 2012; Tierney \& deMenocal, 2013; Van Rampelbergh et al., 2013). These changes likely reflect the northward and westward displacement of ITCZ in response to the increased boreal summer insolation, which affected precipitation and wind forcing. However, our data also suggest that primary productivity declined during the early Holocene. This is not coherent with paleoclimatic records from the western Arabian Sea, which showed that summer upwellings and primary productivity reached a maximum at around $\sim 9 \mathrm{ka}$, in conjunction with the maximum in boreal summer insolation (i.e. Gupta et al., 2011). Further studies including data/model comparisons might help us understand why upwelling intensity in the Gulf of Aden reached a maximum earlier.

The decoupling between our productivity index, on the one hand, and TOC and $\mathrm{Br}$ contents, on the other hand, suggests that organic carbon content in core MD92-1002 could be chiefly related to the preservation at the sea floor rather than the surface productivity.

\section{ACKNOWLEDGEMENTS}

This research was funded by the national research funding agency in France (ANR) through the ELPASO project (ANR-10-BLAN-0608) and the MONOPOL project (ANR-11-BS56-0024). Thanks are due to K. Lemonnier (CNRS LOCEAN) for assistance with laboratory procedure and dinocyst identification and $\mathrm{E}$. Moreno, who ensured the accessibility of samples (MNHN core repository, Paris). XRF analyses were performed at EPOC Laboratory (Bordeaux, France). AMS dating was provided by ARTEMIS, UMS 2572, Laboratoire de Mesure du Carbone 14 (LMC14) (Saclay, France). W.F. and F.B are supported by CEA (France) and A.-M.L. by CNRS (France). This is LSCE contribution 5739. 


\section{REFERENCES}

ABIDI N., 1997 - Les kystes de dinoflagellés marqueurs de l'environnement océanique : répartition actuelle dans l'Océan indien occidental et application à deux séquences sédimentaires du Canal de Mozambique. Thèse de Doctorat, Université Paris 6 Pierre et Marie Curie, Paris, 183 p.

AGNIHOTRI R., SARIN M.M., SOMAYAJULU B.L.K., JULL A.J.T. \& BURR G.S., 2003 - Late-Quaternary biogenic productivity and organic carbon deposition in the eastern Arabian Sea. Palaeogeography, Palaeoclimatology, Palaeoecology, 197 (1-2), 43-60.

ALMOGI-LABIN A., SCHMIEDL G., HEMLEBEN C., SIMAN-TOV R., SEGL M. \& MEISCHNER D., 2000 - The influence of the NE winter monsoon on productivity changes in the Gulf of Aden, NW Arabian Sea, during the last $530 \mathrm{ka}$ as recorded by foraminifera. Marine Micropaleontology, 40 (3), 295-319.

ANDERSON D.M. \& PRELL W.L., 1991 - Coastal upwelling gradient during the late Pleistocene. Proceedings of the Ocean Drilling Program. Scientific Results, 117, 265-276.

ANDERSON D.M. \& PRELL W.L., 1993 - A $300 \mathrm{kyr}$ record of upwelling of Oman during the late Quaternary: Evidence of the Asian southwest monsoon. Paleoceanography, 8 (2), 193-208.

BARD E., HAMELIN B., ARNOLD M., MONTAGGIONI L., CABIOCH G., FAURE G. \& ROUGERIE F., 1996 - Deglacial sea-level record from Tahiti corals and the timing of global meltwater discharge. Nature, 382 (6588), 241-244.

BASSINOT F.C., MARZIN C., BRACONNOT P., MARTI O., MATHIEN-BLARD E., LOMBARD F. \& BOPP L., 2011 - Holocene evolution of summer winds and marine productivity in the tropical Indian Ocean in response to insolation forcing: datamodel comparison. Climate of the Past, 7 (3), 815-829.

BOUILLOUX A., VALET J.-P., BASSINOT F., JORON J.-L., BLANC-VALLERON M.-M., MORENO E., DEWILD, F., KARS M. \& LAGROIX F., 2013a - Diagenetic modulation of the magnetic properties in sediments from the Northern Indian Ocean. Geochemistry, Geophysics, Geosystems, 14 (9), 3779-3800.

BOUILLOUX A., VALET J.-P., BASSINOT F., JORON J.-L., DEWILDE F., BLANC-VALLERON M.-M. \& MORENO E., 2013b - Influence of seawater exchanges across the Bab-el-Mandeb Strait on sedimentation in the Southern Red Sea during the last $60 \mathrm{ka}$. Paleoceanography, 28 (4), 675-687.

BRONK RAMSEY C., 1995 - Radiocarbon calibration and analysis of stratigraphy: The OxCal Program. Radiocarbon, 37 (2), 425-430.

BRONK RAMSEY C., VAN DER PLICHT J. \& WENINGER B., 2001 - "Wiggle matching" radiocarbon dates. Radiocarbon, 43 (2A), 381-389.

CALEY T., MALAIZÉ B., REVEL M., DUCASSOU E., WAINER K., IBRAHIM M., SHOEAIB D., MIGEON S. \& MARIEU V., 2011 - Orbital timing of the Indian, East Asian and African boreal monsoons and the concept of a 'global monsoon'. Quaternary Science Reviews, 30 (25-26), 3705-3715.

CLEMENS S., PRELL W., MURRAY D., SHIMMIELD G. \& WEEDON G., 1991 - Forcing mechanisms of the Indian Ocean monsoon. Nature, 353 (6346), 720-725.

DAVEY R.J. \& ROGERS J., 1975 - Palynomorph distribution in Recent offshore sediments along two traverses off South West Africa. Marine Geology, 18 (4), 213-225.

DE VERNAL A. \& HILLAIRE-MARCEL C., 1987 - Eléments d'une climatostratigraphie du Pléistocène moyen et tardif dans l'est du Canada par l'analyse palynologique et isotopique du forage 84-030003, mer du Labrador. Canadian Journal of Earth Sciences, 24 (9), 1886-1902.

DE VERNAL A. \& PEDERSEN T.F., 1997 - Micropaleontology and palynology of core PAR87A-10: A 23,000 year record of paleoenvironmental changes in the Gulf of Alaska, northeast North Pacific. Paleoceanography, 12 (6), 821-830.

DE VERNAL A., HENRY M., MATTHIESSEN J., MUDIE P.J., ROCHONA., BOESSENKOOL K.P., EYNAUD F., GRØSFJELD K., GUIOT J., HAMEL D., HARLAND R., HEAD M.J., KUNZPIRRUNG M., LEVAC E., LOUCHEUR V., PEYRON O., POSPELOVA V., RADI T., TURON J.-L. \& VORONINA E., 2001 - Dinoflagellate cyst assemblages as tracers of sea-surface conditions in the northern North Atlantic, Arctic and sub-Arctic seas: The new ' $n=677$ ' data base and its application for quantitative palaeoceanographic reconstruction. Journal of.Quaternary Science, 16 (7), 681-698.

DE VERNAL A., EYNAUD F., HENRY M., HILLAIRE-MARCEL C., LONDEIX L., MANGIN S., MATTHIESSEN J., MARRET F., RADI T., ROCHON A., SOLIGNAC S. \& TURON J.-L., 2005 - Reconstruction of sea-surface conditions at middle to high latitudes of the Northern Hemisphere during the Last Glacial Maximum (LGM) based on dinoflagellate cyst assemblages. Quaternary Science Reviews, 24 (7-9), 897-924.

ELSHANAWANY R. \& ZONNEVELD K.A.F., 2016 - Dinoflagellate cyst distribution in the oligotrophic environments of the Gulf of Aqaba and northern Red Sea. Marine Micropaleontology, 124, 29-44.

FAGRI K. \& IVERSEN J., 1975 - Textbook of Pollen Analysis, $3^{\text {rd }}$ revised edition. Blackwell Scientific Publications, Oxford, 295 p.

FAIRBANKS R.G., 1989 - A 17,000-year glacio-eustatic sea level record: influence of glacial melting rates on the Younger Dryas event and deep-ocean circulation. Nature, 342 (6250), 637-642.

FENSOME R.A. \& WILLIAMS G.L., 2004 - The Lentin and Williams index of fossil dinoflagellates, 2004 edition. AASP Contributions Series, 42. American Association of Stratigraphic Palynologists Foundation, College Station, 909 p.

FENSOME R.A., MACRAE R.A. \& WILLIAMS G.L., 2008 - DINOFLAJ2, Version 1. American Association of Stratigraphic Palynologists, Data Series no. 1.

FERSI W., LÉZINE A.-M. \& BASSINOT F., in press - Hydro-climate changes over southwestern Arabia and the Horn of Africa during the last glacial-interglacial transition: A pollen record from the Gulf of Aden. Review of Palaeobotany and Palynology, doi:10.1016/j. revpalbo.2016.04.002.

FLEMING K. \& LAMBECK K., 1998 - Constraints on the Greenland Ice Sheet since the Last Glacial Maximum from sea-level observations and glacial-rebound models. Quaternary Science Reviews, 23 (9-10), 1053-1077.

FOERSTER V., JUNGINGER A., LANGKAMP O., GEBRU T., ASRAT A., UMER M., LAMB H.F., WENNRICH V., RETHEMEYER J., NOWACZYK N., TRAUTH M.H. \& SCHAEBITZ F., 2012 - Climatic change recorded in the sediments of the Chew Bahir basin, southern Ethiopia, during the last 45,000 years. Quaternary International, 274, 25-37.

GRIMM E.C., 1993 - TILIA: A pollen program for analysis and display. Illinois State Museum, Springfield.

GUPTA A.K.,ANDERSON D.M. \& OVERPECK J.T., 2003 - Abrupt changes in the Asian southwest monsoon during the Holocene and their links to the North Atlantic Ocean. Nature, 421 (6921), 354-357.

GUPTA A.K., MOHAN K., SARKAR S., CLEMENS S.C., RAVINDRA R. \& UTTAM R.K., 2011 - East-West similarities and differences in the surface and deep northern Arabian Sea records during the past 21 kyr. Palaeogeography, Palaeoclimatology,Palaeoe cology, 301 (1-4), 75-85.

HEMMING S.R., 2004 - Heinrich events: Massive late Pleistocene detritus layers of the North Atlantic and their global climate imprint. Reviews of Geophysics, 42(1), RG1005, doi:10.1029/2003RG000128.

IHAKA R. \& GENTLEMAN R., 1996 - R: A language for data analysis and graphics. Journal of Computational and Graphical Statistics, 5 (3), 299-314.

IVANOCHKO T.S., GANESHRAM R.S., BRUMMER G.-J.A., GANSSEN G., JUNG S.J.A., MORETON S.G. \& KROON D., 2005 - Variations in tropical convection as an amplifier of global climate change at the millennial scale. Earth and Planetary Science Letters, 235 (1-2), 302-314.

IVANOVA E., SCHIEBEL R., SINGH A.D., SCHMIEDL G., NIEBLER H.-S. \& HEMLEBEN C., 2003 - Primary production in the Arabian Sea during the last 135000 years. Palaeogeography, Palaeoclimatology, Palaeoecology, 197 (1-2), 61-82.

JEAN-BAPTISTE P., BELVISO S., ALAUX G., NGUYEN B.C. \& MIHALOPOULOS N., $1990-{ }^{3} \mathrm{He}$ and methane in the Gulf of Aden. Geochimica et Cosmochimica Acta, 54 (1),111-116.

JUNG S.J.A., KROON D., GANSSEN G., PEETERS F. \& GANESHRAM R., 2009 - Enhanced Arabian Sea intermediate water flow during glacial North Atlantic cold phases. Earth and Planetary Science Letters, 280 (1-4), 220-228.

KUTZBACH J.E. \& STREET-PERROT F.A., 1985 - Milankovitch forcing of fluctuations in the level of tropical lakes from 18 to $0 \mathrm{kyr}$ BP. Nature, 317 (6033), 130-134.

LEWIS J., DODGE J.D. \& POWELL A.L., 1990 - Quaternary dinoflagellate cysts from the upwelling system offshore Peru, Hole 686B, ODP Leg 112. Proceedings of the Ocean Drilling Program. Scientific Results, 112, 323-327.

LUTHER M.E. \& O'BRIEN J.J., 1985 - A model of the seasonal circulation in the Arabian Sea forced by observed winds. Progress in Oceanography, 14, 353-385.

MALAIZÉ B., VÉNEC-PEYRÉ M.-T., JOLY C., BASSINOT F., CAILLON N. \& CHARLIER K., 2009 - Imprints of high-salinity water plumes originating from the Red Sea during termination II. Palaeogeography. Palaeoclimatology, Palaeoecology, 276 (1-4), 69-79. 
MARRET F., 1994 - Distribution of dinoflagellate cysts in recent marine sediments from the east Equatorial Atlantic (Gulf of Guinea). Review of Paleobotany and Palynology, 84 (1-2), 1-22.

MARRET F. \& TURON J.-L., 1994 - Paleohydrology and paleoclimatology off Northwest Africa during the last glacial-interglacial transition and the Holocene: Palynological evidences. Marine Geology, 118 (1-2), 107-117.

MARRET F. \& DE VERNAL A., 1997 - Dinoflagellate cyst distribution in surface sediments of the southern Indian Ocean. Marine Micropaleontology, 29 (3-4), 367-392.

MARRET F. \& ZONNEVELD K.A.F., 2003 - Atlas of modern organicwalled dinoflagellate cyst distribution. Review of Palaeobotany and Palynology, 125 (1-2), 1-200.

MATHIEN-BLARD E., 2008 - Révision du paléothermomètre $M g$ Ca et son application sur l'hydrologie de surface de l'Océan Indien Tropical au cours de l'Holocène. Thèse de Doctorat, Université Paris-Sud, Orsay, $202 \mathrm{p}$.

MATTHIESSEN J., 1995 - Distribution patterns of dinoflagellate cysts and other organic walled microfossils in recent NorwegianGreenland Sea sediments. Marine Micropaleontology, 24 (3-4), 307-334.

MORCOS S.A. \& ABDALLAH A.M., 2013 - Oceanography of the Gulf of Aden: John Murray-Mabahiss Expedition 1933-1934 Revisited. The Egyptian Journal of Aquatic Research, 38 (2), 77-91.

MUDIE P.J., ROCHONA. \& LEVAC E., 2002 - Palynological records of red tide-producing species in Canada: past trends and implications for the future. Palaeogeography, Palaeoclimatology, Palaeoecology, 180 (1-3), 159-186.

NAIDU P.D., \& MALMGREN B.A., 1996 - A high-resolution record of Late Quaternary upwelling along the Oman Margin, Arabian Sea based on planktonic foraminifera. Paleoceanography, 11 (1), $129-140$

NAIDU, P.D., \& NIITSUMA., 2003 - Carbon and oxygen isotope time series records of planktonic and benthic foraminifera from the Arabian Sea: implication on upwelling processes. Palaeogeography, Palaeoclimatology, Palaeoecology, 202 (1-2), 85-95.

NARALE D.D., NAIDU P.D., ANIL A.C. \& GODAD S.P., 2015 Evolution of productivity and monsoonal dynamics in the eastern Arabian Sea during the past $68 \mathrm{ka}$ using dinoflagellate cys records. Palaeogeography, Palaeoclimatology, Palaeoecology, $\mathbf{4 3 5}$, 193-202.

OUAHDI R., 1997 - Paléocéanographie et paléoproductivité liées à la mousson indienne dans le bassin de Somalie, le golfe d'Aden et la mer Rouge durant les derniers 460000 ans. Thèse de Doctorat, Muséum national d'Histoire Naturelle, Paris, $166 \mathrm{p}$

OVERPECK J., ANDERSON D., TRUMBORE S., \& PRELL W., 1996 - The southwest Indian Monsoon over the last 18000 years. Climate Dynamics, 12, 213-225.

PICKARD G. L. \& EMERY W. J., 1982 - Descriptive physical oceanography: an introduction, $4^{\text {th }}$ enlarged edition. Pergamon Press, Oxford \& New York, $247 \mathrm{p}$.

POSPELOVA V., PEDERSEN TF, \& DE VERNAL A, 2006 Dinoflagellate cysts as indicators of climatic and oceanographic changes during the past $40 \mathrm{kyr}$ in the Santa Barbara Basin, southern California. Paleoceanography, 21 (2), 1-16.

PRELL W.L. \& CURRY W.B., 1981 - Faunal and isotopic indices of monsoonal upwelling: Western Arabian Sea. Oceanologica Acta, 4 (1), 91-98

PRELL W.L., 1984 - Variations of monsoon upwelling: A response to changing in the solar radiation. In J. Hansen \& T. Takahashi (eds.), Climate Processes and Climate Sensitivity. Geophysical Monograph, 29 \& Maurice Ewing Series, 5. American Geophysical Union, Washington D.C., 48-57.

PRELL W.L., \& VAN CAMPO E., 1986 - Coherent response of Arabian Sea upwelling and pollen transport to late Quaternary monsoonal winds. Nature, 323 (6088), 526-528.

PRELL W.L., \& KUTZBACH J.E., 1987 - Monsoon variability over the past 150,000 years. Journal of Geophysical Research, 92 (D7), 8411-8425.

RADI T., DE VERNAL A. \& PEYRON O., 2001 - Relationships between dinocyst assemblages in surface sediments and hydrographic conditions in the Bering and Chukchi seas. Journal of Ouaternary Science, 16 (7), 667-680.

REICHART G.-J. \& BRINKHUIS H., 2003 - Late Quaternary Protoperidinium cysts as indicators of paleoproductivity in the northern Arabian Sea. Marine Micropaleontology, 49 (4), 303-315.

REIMER P.J., BROWN T.A. \& REIMER R.W., 2004 - Discussion: reporting and calibration of post-bomb ${ }^{14} \mathrm{C}$ data. Radiocarbon, 46 (3), 1299-1304.
ROSTEK F., BARD E., BEAUFORT L., SONZOGNI C. \& GANSSEN G., 1997 - Sea surface temperature and productivity records for the past $240 \mathrm{kyr}$ in the Arabian Sea. Deep-Sea Research. Part 2, Topical Studies in Oceanography, 44 (6-7), 1461-1480.

SCHULZ H., VON RAD U., \& ERLENKEUSER H., 1998 Correlation between Arabian Sea and Greenland climate oscillations of the past 110,000 years. Nature, 393 (6680), 54-57.

SHAKUN J.D., BURNS S.J., FLEITMANN D., KRAMERS J., MATTER A. \& AL-SUBARY A., 2007 - A high-resolution, absolute-dated deglacial speleothem record of Indian Ocean climate from Socotra Island, Yemen. Earth and Planetary Science Letters, 259 (3-4), 442-456.

SIDDALL M., ROHLING E., ALMOGI-LABIN A., HEMLEBEN C., MEISCHNER D., SCHMELZER I. \& SMEED D.A., 2003 Sea-level fluctuations during the last glacial cycle. Nature, $\mathbf{4 2 3}$ (6942), 853-858.

SINGH A.D., JUNG S.J.A., DARLING K., GANESHRAM R., IVANOCHKO T. \& KROON D., 2011 - Productivity collapses in the Arabian Sea during glacial cold phases. Paleoceanography, 26 (3), PA3210, doi:10.1029/2009PA001923.

SIROCKO F, SARNTHEIN M., LANGE H. \& ERLENKEUSER H., 1991 - Atmospheric summer circulation and coastal upwelling in the Arabian Sea during the Holocene and the last glaciation. Quaternary Research, 36 (1), 72-93.

SIROCKO F., SARNTHEIN M., ERLENKEUSER H., LANGE H., ARNOLD M. \& DUPLESSY J.-C., 1993 - Century-scale events in monsoonal climate over the past 24,000 years. Nature, 364 (6435), $322-324$

SOUTHON J., KASHGARIAN M., FONTUGNE M., METIVIER B., \& YIM W.W.-S., 2002 - Marine reservoir corrections for the Indian Ocean and Southeast Asia. Radiocarbon, 44 (1), 167-180.

SWALLOW J.C., 1984. Some aspects of the physical oceanography of the Indian Ocean. Deep-Sea Research. Part A, Oceanographic Research Papers, 31 (6-8), 639-650.

TIERNEY J.E. \& DE MENOCAL P.B., 2013 - Abrupt Shifts in Horn of Africa Hydroclimate since the Last Glacial Maximum. Science, 342 (6160), 843-846

VAN COUWELAAR M., 1997 - Zooplankton and micronekton biomass off Somalia and in the southern Red Sea during the SW monsoon of 1992 and the NE monsoon of 1993. Deep-Sea Research. Part 2, Topical Studies in Oceanography, 44 (6-7), 1213-1234.

VAN RAMPELBERGH M., FLEITMANN D., VERHEYDEN S., CHENG H., EDWARDS L., DE GEEST P., DE VLEESCHOUWER D., BURNS S.J., MATTER A., CLAEYS P. \& KEPPENS E., 2013 - Mid- to late Holocene Indian Ocean Monsoon variability recorded in four speleothems from Socotra Island, Yemen. Quaternary Science Reviews, 65, 129-142.

VERSTEEGH G.J.M. \& ZONNEVELD K.A.F., 1994 - Determination of (palaeo-)ecological preferences of dinoflagellates by applying Detrended and Canonical Correspondence analysis to Late Pliocene dinoflagellate cyst assemblages of the south Italian Singa section. Review of Palaeobotany and Palynology, 84 (1-2), 181-199.

VERSTEEGH G.J.M., BRINKHUIS H., VISSCHER H. \& ZONNEVELD K.A.F., 1996 - The relation between productivity and temperature in the Pliocene North Atlantic at the onset of northern hemisphere glaciation: a palynological study. Global and Planetary Change, 11 (4), 155-165.

WALL D., DALE B., LOHMAN G.P. \& SMITH W.K., 1977 - The environmental and climatic distribution of dinoflagellate cysts in modern sediments from regions in the North and South Atlantic oceans and adjacent seas. Marine Micropaleontology, 2, 121-200.

WYRTKI K., 1973 - Physical oceanography of the Indian Ocean. In B. Zeitschel (ed.), The Biology of the Indian Ocean. Ecological Studies, 3. Springer, New York, 18-36

ZIEGLER M., JILBERT T., DE LANGE G.J., LOURENS L.J. \& REICHART G.-J., 2008 - Bromine counts from XRF scanning as an estimate of the marine organic carbon content of sediment cores. Geochemistry, Geophysics, Geosystems, 9 (5), Q05009. doi:10.1029/2007GC001932.

ZONNEVELD K.A.F., 1996 - Paleoclimatic and paleo-ecologic changes in the Eastern Mediterranean and Arabian Sea regions during the last deglaciation: a palynological approch to landSea correlation. LPP Contributions Series, 5. Ponsen \& Looijen, Wageningen, $200 \mathrm{p}$.

ZONNEVELD K.A.F., 1997 - Dinoflagellate cyst distribution in surface sediments from the Arabian Sea (northwestern Indian Ocean) in relation to temperature and salinity gradients in the upper water column. Deep-Sea Research. Part 2, Topical Studies in Oceanography, 44 (6-7), 1411-1443. 
ZONNEVELD K.A.F., GANSSEN G., TROELSTRA S., VERSTEEGH G.J.M., \& VISSCHER H., 1997a - Mechanisms forcing abrupt fluctuations of the Indian Ocean summer monsoon during the last deglaciation. Quaternary Science Review, 16 (2), 187-201.

ZONNEVELD K.A.F., VERSTEEGH G.J.M. \& DE LANGE G.J., 1997b - Preservation of organic-walled dinoflagellate cysts in different oxygen regimes: a 10,000 year natural experiment. Marine Micropaleontology, 29 (3-4), 393-405.

ZONNEVELD K.A.F. \& BRUMMER G.-J.A., 2000 - (Palaeo-) ecological significance, transport and preservation of organic-walled dinoflagellate cysts in the Somali Basin, NW Arabian Sea. Deep-Sea Research. Part 2, Topical Studies in Oceanography, 47 (9-11), 22292256.

ZONNEVELD K.A.F., BOCKELMANN F. \& HOLZWARTH U., 2007 - Selective preservation of organic-walled dinoflagellate cysts as a tool to quantify past net primary production and bottom water oxygen concentrations. Marine Geolology, 237 (3-4), 109-126.
ZONNEVELD K.A.F., MARRET F., VERSTEEGH G.J.M., BOGUS K., BONNET S., BOUIMETARHAN I., CROUCH E., DE VERNAL A., ELSHANAWANY R., EDWARDS L., ESPER O., FORKE S., GRØSFJELD K., HENRY M., HOLZWARTH U., KIELT J.-F., KIM S.-Y., LADOUCEUR S., LEDU D., LIANG C., LIMOGES A., LONDEIX L., LU S.-H., MAHMOUD M.S., MARINO G., MATSOUKA K., MATTHIESSEN J., MILDENHAL D.C., MUDIE P., NEIL H.L., POSPELOVA V., QI Y., RADI T., RICHEROL T., ROCHON A., SANGIORGI F., SOLIGNAC S., TURON J.-L., VERLEYE T., WANG Y., WANG Z. \& YOUNG M., 2013 - Atlas of modern dinoflagellate cyst distribution based on 2405 data points. Review of Palaeobotany and Palynology, 191, 1-197. 